THE TYNDALE NEW TESTAMENT LECTURE, 1981

\title{
UNDERSTANDING MISUNDERSTANDINGS IN THE FOURTH GOSPEL
}

\section{By Donald A. Carson}

Conventional wisdom assures us, in the words of the bard, that 'a rose by any other name would smell as sweet'. Conventional wisdom is doubtless right: labels cannot change ontology. But labels, especially half true labels, can breed a great deal of misunderstanding, and bruise reputations rather severely. Even the rose would suffer a serious decline in esteem if for a period of ten years every published reference to it included some such description as the following: 'a prickly plant of the genus rosa, whose spikes make it difficult to handle, and whose scent, though found pleasant by some, cannot make up for its destructive potential as a notoriously fertile breeding ground for aphids, a dangerous form of plant lice; and whose most characteristic colour explains the association of the expression "the rose", in popular parlance, with erysipelas, an inflammatory cutaneous disease frequently accompanied by fever in which the skin assumes a frightening, deep red hue'.

Lest anyone be alarmed, I am not about to embark on a moralizing plea that we cease using all labels; for then we would have to stop talking, writing and thinking. It is simply a way of saying that labels, which help us organize our thoughts, enable us to communicate, and reduce complex conceptions to easily communicable proportions, can also, wittingly or unwittingly, distort, malign, conceal and blur. In NT studies, one need only think of such slippery expressions as 'Jewish Christianity', 'eschatology' and 'salvation history'. In these cases, the labels are tricky because in the literature they are used with a profusion of meanings. By contrast, in the case I want to consider, the meaning of the expression 'literary device' is fairly stable and comprehensible. Yet in the sentence, 'Misunderstandings are a Johannine literary device', the label 'literary device', though technically accurate (like my gloomy description of a rose), is nevertheless an inadequate description of an important and recurring phenomenon. Misunderstandings in the fourth gospel 
will themselves be misunderstood if they are reduced to the dimensions of a 'literary device'.

I shall begin by describing the most important literature on misunderstandings in John. Then I shall offer a brief critique, followed by a number of positive observations which will, I hope, shed a little light not only on John's 'literary device' of misunderstandings, but on his entire gospel.

In 1948, Oscar Cullmann published a perceptive article in which he points out how many words in John have a double or at least ambiguous meaning (metaphors aside). ${ }^{1}$ Such

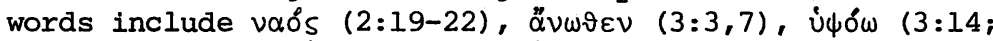

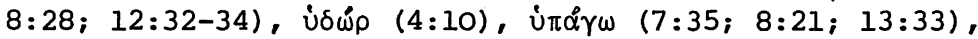

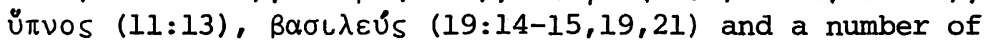
others. Many, though not all, have both a physical and a spiritual meaning; and they frequently give rise to misunderstandings which serve to advance the argument. So, for instance, in the interview with Nicodemus: the ruler fails to understand what Jesus means by the clause

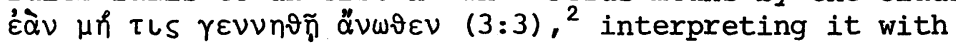
pedantic literalness. This gives Jesus opportunity to explain what he means in greater detail. Sometimes the advance in the pericope is achieved, not by further explanation by Jesus, but by an aside from the evangelist once the misunderstanding is noted (e.g. 2:19-22). In

1. O. Cullmann, 'Der johanneische Gebrauch doppeldeutigen Ausdrücke als Schlüssel zum Verständnis des vierten Evangeliums', TZ 4 (1948) 360-72; reprinted in Vorträge und Aufsätze 1925-1962 (Tübingen: Mohr/ Zürich: Zwingli, 1966) 176-186.

2. In fact several misunderstandings are probably presupposed by v. 4. In particular, Nicodemus thinks of

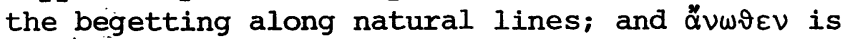
t'aken by him to mean 'again', though it probably means 'from above'. The latter point is disputed. R. Bultmainn, The Gospel of John: A Commentary (Oxford: Blackwell, 1971) $135 \mathrm{n} .1$ insists that Jôhannine misunderstandings never depend on verbal ambiguity but this is clearly wrong, as we shall see (cf. references under Col. 9 of the chart). The word ă $\nu \omega \vartheta \varepsilon \nu$ elsewhere in John always means 'from above' $(3: 31 ; 19: 11,23)$, and the ensuing discussion suggests that is also the case here. 
both cases, however, it is the misunderstanding itself which triggers the advance. Cullmann sees this device as a key which opens up the gospel of John.

The only full-length monograph on the subject began as a doctoral dissertation by $\mathrm{H}$. Leroy. ${ }^{3}$ His study is primarily form-critical. Although Johannine misunderstandings have features in common with irony, oracles and Cullmann's double meanings, Leroy finds that on formal grounds they really belong to a special class of riddle (Rätsel), viz. riddles concealed in a dialogue. Such riddles, he says, use words in two ways, a general meaning for 'outsiders' and a special meaning for 'insiders'. Leroy isolates eleven misunderstandings of this type, all between John 2 and John 8 inclusive $(2: 19-22 ; 3: 3-5 ; 4: 10-15 ; 4: 31-34 ; 4: 32-35,41 f ; 6: 51-53$; $7: 33-36$ and $8: 21 f ; 8: 31-33 ; 8: 51-53 ; 8: 56-58)$. These, he says, are a Johannine peculiarity; and half of Leroy's book is given over to a detailed exegesis of them. Possible parallels in the synoptics he discounts on various grounds.

In the eleven misunderstandings which Leroy isolates, Jesus is always on the 'inside'; but in Leroy's view, Jesus simply represents the Johannine Christian community. The 'outsiders' are usually Jews who do not understand, for instance, the special meaning of $\dot{u} \pi \alpha$ r $w$ $(7: 33-36 ; 8: 21 f)$ or of $\dot{a}$ a̋ptos toũ oủpavoũ $(6: 32-35)$. In one instance, however, the 'outsider', the one who misunderstands, is a Samaritan woman (4:10-15), and in another it is the disciples $(4: 31-34)$.

From this base, Leroy attempts to reconstruct the Johannine community which produced such literature. He concludes it must be a gnosticizing group which believes that it is living in the eschatological times of salvation, and that it enjoys an exclusive understanding

3. H. Leroy, Rätsel und Missverständnis: Ein Beitrag zur Formgeschichte des Johannesevangeliums (Bonn:

Hanstein, 1966). Leroy summarizes his main points in a brief article, 'Las johanneische Missverständnis als literarische Form', Bibel und Leben 9 (1968) 196207. 
of revelation. The central idea of their belief system is that Jesus by his passion and death went (Uं⿰彳) share in the glory of his Father. Because of this, his earlier life and ministry must be interpreted in the light of that glory, and therefore Jesus must also be reckoned one who has come down from heaven. The Christians of John's community are privileged to have this special insight of revelation because (1) they enjoy the presence of the Paraclete who interprets Jesus' words, and (2) they have teachers whose doctrine draws on eyewitness traditions about Jesus. It follows that the Sitz im Leben of Johannine misunderstandings is, correspondingly, (1) preaching in the community liturgy, where the Paraclete's voice is heard in the kerygma, and

(2) catechesis, where the traditions about Jesus are taught.

From this, Leroy suggests, the outsiders are easily identified. Most of John's community, which is Jewish Christian as well as gnosticizing, lives in tension with the synagogue, which does not understand the special revelation. Whether we think of John's community as a scattering of small groups over an extended area, or envisage separate layers of tradition and experience within a common history, we may say that two smaller parts of the Johannine community have links with other groups. One is a gathering of Samaritans who, though as Christians tracing their faith to Jesus, have not yet grasped his significance as descending/ascending revealer of the Father; and the other is a number of Jewish catechumens who need full instruction in the special understanding of revelation claimed by John's church. These two smaller groups, of course, answer to the two exceptional 'outsiders' in Leroy's list of eleven cases - viz. the Samaritan woman and the disciples.

I shall more briefly summarize subsequent studies. Writing on John's literary devices, D. W. Wead declines to treat misunderstandings as a separate category. ${ }^{4}$ He holds they are already subsumed under his treatment

4. D. W. Wead, The Literary Devices of John's Gospel (Basel: Reinhardt, 1970) 69-70. 
of irony, double meaning and ambiguous 'signs'. Thus in contradistinction to Leroy, whose work appeared too late for Wead to use, he does not think that Johannine misunderstandings adopt distinctive forms and emerge from well-defined Sitze im Leben. Rather, he treats misunderstandings in John's gospel as a general phenomenon which cannot be categorized without reference to better defined literary devices. By and large, Wead does not attempt to relate his literary analysis to historical and theological questions, though at the beginning of his book he offers a few general reflections which are helpful, and to which I shall refer again (see note 41 ).

Three other studies deserve mention. First, Kim Dewey focuses attention on thirty-four proverbial sayings in the gospel of John. ${ }^{5}$ Most of her study is not relevant to my concerns in this paper; but she offers perceptive remarks on individual proverbs which have a bearing on Johannine misunderstandings. She notes, for instance,

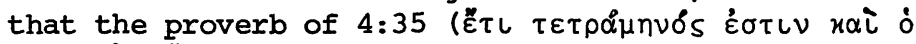

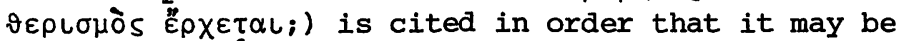
contradicted. ${ }^{6}$ As far as the evangelist is concerned, Jesus thinks the proverb provides, in the circumstances of his disciples, a potential for misunderstanding; and he therefore overturns it. Moreover, although the matter is not her concern, Dewey's work illustrates one reason why the form-critical establishment of Sitze im Leben is precarious; for here is a literary form (a proverb) within a literary form (a 'misunderstanding', if Leroy's category can be maintained, whether on his terms or another's) within a literary form (a dialogue) within a literary form (a gospel). One could imaginatively reconstruct a plausible sitz for each level of form!

The second study is that of C. H. Giblin, who in an article published in 1980 observes that there are four passages in John's gospel (viz. 2:1-11; 4:46-54; 7:2-14; $11: 1-44$ ) with a peculiar sequence. ${ }^{7}$ First, someone

5. Kim E. Dewey, 'Paroimiai in the Gospel of John', Semeia 17 (1980) 81-100.

6. Ibid. 86.

7. C. H. Giblin, 'Suggestion, Negative Response, and Positive Action in St John's Portrayal of Jesus (John 2:1-11; 4:46-54; 7:2-14; 11:1-44)', NTS 26 (1979/80) 197-211. 
suggests that Jesus should take a particular course of action in view of some need or pressing concern; second, Jesus responds negatively to the suggestion; and third, Giblin nevertheless argues that in none of the four instances of this pattern does Jesus act inconsistently. Moreover, Jesus never fails to attend to the situation presented to him; but even though in each case the petitioner is either close or at least not opposed to him (they are, respectively, his mother, a fellow Galilean, his relatives, and his close friends from Bethany), Jesus distances himself from their concerns by taking radical remedial action on his own terms.

The closest synoptic parallel is the episode of the Syrophoenician woman (Mark 7:24-30; Matt. 15:21-28); but there, though the petitioner is rebuffed, she cleverly grasps Jesus' viewpoint, sides with it, and rephrases her plea to accord with it. She perceives Jesus' primary purpose, and articulates her faith in full accordance with that purpose. By contrast, in the four passages in John studied by Giblin, there is no indication that the petitioner fully grasps the significance of Jesus' rebuff. 8

Now none of these four passages appears on Leroy's restricted list of 'misunderstandings'; but, whatever their formal literary characteristics, it is quite clear that in all of them Jesus is in some measure misunderstood. It follows that Leroy's categories are not broad enough if our purpose is to wrestle comprehensively with misunderstandings in the fourth gospel.

If the essays by Dewey and Giblin bear on the formal, literary configurations of certain misunderstandings in John, the third study, a 1971 article by M. de Jonge, deals almost exclusively with the nature of understanding and misunderstanding in one pericope (viz. 3:1-21; cf. vv. 31-36). ${ }^{9}$ Leaning to some extent on J. L.

8. Some would argue this point, but it will stand close scrutiny. Nevertheless Giblin's four pericopae may be too neatly conjoined; $c f$. further discussion below.

9. M. de Jonge, 'Nicodemus and Jesus: Some Observations on Misunderstanding and Understanding in the Fourth Gospel', BJRL 53 (1970/71) 337-359. 
Martyn, 10 de Jonge concludes: 'Misunderstanding is not a matter of understanding incompletely or inaccurately, it reveals a fundamental lack of understanding. And true understanding is a matter of grace, a gift to be granted by God himself, an inward change under the impulse of the Spirit.'11 The evangelist denies that the messianic issue can be reduced to the level of a midrashic disputation between church and synagogue. What is needed is a personal confrontation with Jesus by the Spirit. The strength of de Jonge's study is that it recognises at least some of the factors necessary for bringing about true understanding; but as we shall see, it too suffers from the neglect of one crucial consideration.

Finally, I shall mention how the theme of 'misunderstanding' in John is handled in several commentaries. $R$. Bultmann considers it to be a literary device drawn from Hellenistic revelation literature. ${ }^{12}$ R. E. Brown frequently draws attention to the fourth gospel's misunderstandings, and acknowledges that they may in part owe their existence to studied literary technique, since they usually prompt the Johannine Jesus to go on and explain himself. ${ }^{3}$ But against Leroy, Brown ${ }^{14}$ insists that these misunderstandings are the Johannine equivalent of parabolic language in the synoptic gospels, reflecting the world's inability to perceive the truth. They are therefore not a Johannine peculiarity; and it is quite unhelpful to consider them as 'riddles'. C. K. Barrett's view is somewhat similar. He relies on the article by Cullmann, already discussed, to point out how many misunderstandings in the fourth gospel depend on words and expressions with double or ambiguous

10. J. L. Martyn, History and Theology in the Fourth Gospel (Nashville: Abingdon, 1968, 1979²).

11. de Jonge, 'Nicodemus and Jesus', 359.

12. John 127 note 1.

13. E.g. R. E. Brown, The Gospel according to John (Garden City: Doubleday, 1966, 1970) 130, 138-9, $170,181,264,308,349,566,892$, 1009.

14. Brown, John, exxxv-cxxxvi; idem, review of $\mathrm{H}$. Leroy (Rätsel) in Bib 51 (1970) 152-4. 
meanings; ${ }^{15}$ but he insists nonetheless that Johannine misunderstandings 'are more than a literary trick employed by a writer given to irony. They represent in miniature the total reaction of Judaism to Christ; the Jews perceived only what was superficially visible in Jesus and naturally resisted as absurd the supposition that he should be the Son of God; if they had penetrated beneath the surface they would have seen its truth.'16 E. Haenchen cites Leroy's study approvingly in connection with John $11: 11$, though Leroy himself disallows John 11:11 from his list of tightly defined misunderstandings. ${ }^{17}$ Elsewhere, Haenchen asserts without argument that the misunderstandings found in John 11, for instance, were not part of the original story as he reconstructs it. ${ }^{18}$

The first volume of J. Becker's commentary devotes an excursus to misunderstandings in John. ${ }^{19}$ In brief, Becker says that misunderstandings are the literary composition of the evangelist, and function within a well defined scheme. Misunderstanding is not based on a false understanding of a word, but on an earthly understanding. The believer alone perceives the spiritual understanding. Misunderstanding is thus a sign of unbelief, and therefore reflects Johannine dualism. Seen this way, misunderstanding (Missverständnis) characteristic of unbelieving Jews, is to be sharply distinguished from the non-understanding (Unverständnis) of the disciples, who do not misunderstand by adopting an earthly meaning, but simply lack instruction - a lack Jesus promptly makes up. There is, says Becker, but one exception to this distinction between Missverständnis and Unverständnis, namely 4:3lff, where the disciples misunderstand by adopting an earthly meaning for the word 'food'; but Becker says that because Jesus promptly clears away the disciples' misunderstanding, this is an exception which

15. C. K. Barrett, The Gospel according to St John (London: SPCK, 1978) 208.

16. Ibid. 200.

17. Haenchen, Johannes Evangelium: Ein Kommentar, ed. U. Busse (Tübingen: Mohr, 1980) 401.

18. Ibid. 415.

19. Becker, Das Evangelium des Johannes. Kapitel 1-10 (Gütersloh: Mohn/Würzburg: Echter-Verlag, 1979) 135-136. 
only proves the rule. Becker's approach depends in part on the monograph by Leroy and the stance of Bultmann, though some of his conclusions are distinctive. He does not adequately consider the instances of misunderstanding which turn on more than verbal ambiguity.

There are other discussions of Johannine misunderstandings, tucked away in commentaries and assorted monographs on John; ${ }^{20}$ but the ones already mentioned represent the dominant positions in current study. That they vary as much as they do ensures that a legitimate critique cannot use a shotgun. But though these treatments differ with one another in certain respects, and offer a variety of stimulating insights, all of them betray one fundamental weakness of considerable importance to the interpretation of the gospel of John.

Before elucidating this point, a selective critique may prepare the ground. To do this, I must provide some notes explaining the accompanying chart (see end of article).

The chart provides a convenient breakdown of all the places in the fourth gospel where, explicitly or implicitly, there is misunderstanding or failure to understand. The rows provide the gospel reference, the columns a number of categories describing elements which may or may not be involved in any given passage. Some of the judgments could be disputed, but not many: the chart for the most part represents hard data. Where a judgment is particularly uncertain, I have indicated it with a question mark. Some notes follow:

20. R. A. Culpepper has kindly shown me a draft copy of a chapter, 'Misunderstanding, Irony, and Symbolism', of his forthcoming book, tentatively titled Anatomy of the Fourth Gospel. I saw it only after completing this paper. Though his conclusions are somewhat different from my own, I do not see any reason to modify my judgments. In any case I am grateful for some mutually beneficial discussions with him. 
Scripture references: Occasionally these overlap (11: 1-44 and subsequent entries), because there is some kind of misunderstanding within a misunderstanding. In this instance (11:1-44), Giblin's structure embraces all forty-four verses, but within that passage are two further points of confusion: the meaning of $\Lambda$ ácapos o

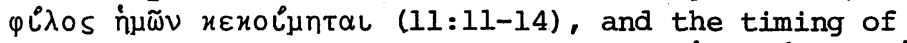

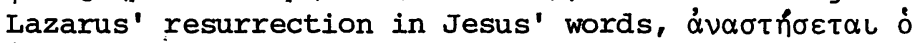
$\alpha \delta \varepsilon \lambda \varphi \delta s$ бov (11:21-44). Moreover, each reference does not necessarily embrace only one misunderstanding: in 3:3-6, regarding birth from above, there are at least two points of confusion (see note 2); and in 2:19-22, concernconcerning Jesus' body as the temple, there are two separate groups who fail to understand - i.e. the Jews misunderstand and, according to the evangelist, the disciples fail to understand until after the resurrection. Thus, of these two groups which fail to grasp the significance of Jesus' temple saying, one explicitly misunderstands, and the other implicitly fails to understand until a specified time. The chart does not distinguish the two groups at every point along the row, but a little care in reading the chart makes the distinction obvious.

The references on the chart specify the extent of text in which the principal focus occurs; but in a few instances a broader context must be included to explain why certain columns are marked (e.g. at 8:18-20, Col. 17 is marked because $8: 28$, which shows that resolution of this misunderstanding requires the passage of time, still deals with the misunderstanding of 8:18-20). I should also add that one or two passages which might have claimed the right to be represented on the chart have been excluded on the grounds that a plausible case can be made for interpreting them without resorting to the category of misunderstanding (e.g. हैp yov in 6:28-29: see the recent essay by U. C. von Wahlde ${ }^{21}$ ).

Col. 1: These marks list the eleven passages isolated by Leroy. In one case, however, I have separated verses which he lumps together, because distinguishable features are involved (as the marks along the rows indicate). In $6: 32-35$, the Jews do not understand the expression o

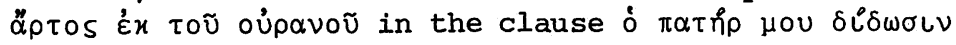

21. U. C. von Wahlde, 'Faith and Works in Jn vi 28-29', NovT 22 (1980) 304-315. 


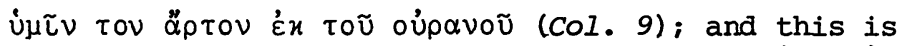

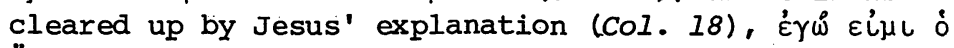
åptos $\tau \tilde{n} S \zeta \omega \tilde{n} s(6: 35)$. In $6: 41-42$, however, there is no verbal ambiguity. The Jews do not misunderstand some term Jesus is using: rather, they cannot accept that the Jesus whose family they know is the bread from heaven. Thus, they fail to understand who Jesus is (Col. 7), and, in the context, the nature of his mission (Col. 8), a failure which also underlies the merely verbal ambiguity in the earlier verses $(6: 32-35)$. In $6: 41-42$, therefore, no explanation by Jesus suffices (Col. 18). Leroy has lumped together rather different phenomena.

Col. 2: The four instances of implicit misunderstanding isolated by Giblin exhibit essentially the same phenomena, the chief difference being that the identity of those rebuffed by Jesus has no consistency. The chart is probably not discriminating enough to show up other differences among the four cases. For instance, the first 'request' (2:3-7) is not very specific, more like an openended description of the need; the second $(4: 46-54)$ is for a healing miracle; the third $(7: 2-14)$ is that Jesus submit to a greater degree of public exposure; and the fourth

(11:1-44) is, presumably, an implicit request for healing. Note, too, that similar misunderstandings are found in many passages: it is the rebuff sequence which makes Giblin's four stand out, and this the chart does not indicate. I have not marked Col. 18 in Giblin's four cases, though arguably the passage of time would remove some of the misunderstanding displayed by each interlocutor. As the text does not make this very explicit, I have left that column blank.

Cols. 3-5: These columns are fairly self-explanatory. In 2:19-22, observe the distinction between the two groups (Cols. 3,5). The question mark at the first entry of col. 4 arises out of uncertainty as to the force of ou $\mu \alpha \tau \varepsilon \hat{\varepsilon} \alpha \beta \varepsilon \nu$ ('the darkness has not understood the light' or ' has not overcome the light'). On each row, at least one of Cols. 3, 4 or 5 must be marked; and Col. 19 may be marked as well (see below).

Col. 6: This indicates the passages in which a misunderstanding or a failure to understand has been set in a context where some contrast is drawn between those who fail and those who do understand, however dimly. 
Cols. 7-10: These specify what is misunderstood or not understood. The columns are not mutually exclusive. Cols. 7, 8 betray failure at a very deep level, and they are among the most heavily marked columns on the chart. Col. 9 indicates passages where the failure turns on some verbal ambiguity; but of course, failure at that level may betray something much deeper. In Col. 10, the first three misunderstood deeds are signs/miracles, and the last is the footwashing.

Cols. 11-14: These columns specify who has misunderstood, or failed to understand. At least one of these four columns is marked for each passage. The 'others' category (Col. 14) is surprisingly diverse: it includes the world, the master of ceremonies at the wedding in Cana, the samaritan woman, the friends at Bethany, and Pilate. In Col. 13, 'Jews' is not a purely racial category, but refers to crowds and/or Jewish leaders who do not belong to a specified category (disciples, family) and who are racially Jewish.

Cols. 15-18: These columns indicate what must happen for the misunderstanding to be cleared up, or for the failure to understand to be overcome. Sometimes there is simply a demand that people believe, or the like (Col. 16). At other times the solution turns on some initiative by God or Jesus (Col. 15), sometimes in terms of election (e.g. $6: 41-44)$, sometimes in terms of specific revelation (e.g. 1:29-34), sometimes in terms of personal selfdisclosure (e.g. 9:17,35-38). The interplay between these two columns (Cols. 15, 16) is part of a broader pattern in John's gospel, a pattern which interweaves God's sovereignty and man's responsibility, something I have discussed elsewhere. ${ }^{2.2} \mathrm{Col} .17$ will prove of central importance to the final section of this paper. In almost every case, the 'passage of time' in question is the period between the described misunderstanding and Jesus' death and resurrection. In two cases this 'temporal' solution to the misunderstanding is far enough on in the text from the description of the misunderstanding itself that the verses where the solution occurs are listed in parentheses.

22. D. A. Carson, Divine Sovereignty and Human Responsibility: Biblical Perspectives in Tension (London: Marshall, 1981). 
Col. 19: I have hesitated to include this column, because it embraces two quite different phenomena: (1) instances of false faith, and (2) instances of true yet very immature faith. Almost any case of faith in Jesus before the resurrection probably belongs in some sense to one of these two categories; but I have not included them unless there is some specific reason for thinking one of these two categories is in the evangelist's mind. What the passages belonging to this column have in common in some measure of mis- or noncomprehension, despite the profession of belief or of understanding.

As we have seen, at least one of Cols. 3, 4, 5 must be marked on each row. Whenever Col. 19 is also marked, it is in conjunction with Col. 5 , a subset of Col. 5 if you like, since the misunderstanding in Col. 19 is, in the nature of the case, invariably implicit. One could argue that col. 19 therefore properly belongs adjacent to Col. 5; but, again with some hesitation, I have adopted the present arrangement because the phenomena of Col. 19 are sufficiently distinctive - they are, after all, confessions - that perhaps it is more realistic to separate them a little from the main evidence for misunderstandings and failed understandings.

Col. 20:- John's frequent asides have been studied by M. C. Tenney and J. J. O'Rourke. ${ }^{23}$ The list in this column includes only those which shed light on some misunderstanding or failure to understand; for John offers a plethora of asides not relevant to our theme.

\section{III}

The data in the chart encourage a critique along the lines of the following five points, not all of which apply equally to all the studies already described.

1. The magnificent diversity of the phenomena militates against any theory which reductionistically squeezes certain instances of 'misunderstanding' into a narrowly defined form-critical mould, and excludes everything

23. M. C. Tenney, 'The Footnotes of John's Gospel', BS 117 (1960) 350-364; J. J. O'Rourke, 'Asides in the Gospel of John', NovT 21 (1979) 210-219. 
else. Careful study of the chart reveals interesting differences among the eleven cases isolated by Leroy

(quite apart from his mistaken interpretation of $6: 32-35$, 41-4l, discussed abovel; and, equally interesting, there are other entries on the chart which have all the characteristics of one or another of Leroy's eleven, yet they are excluded from his list. Bultmann, as we have seen, seeks a background in the Hellenistic revelation literature; but none of his cited examples parallels the phenomena of Col. 17, where the removal of misunderstanding or the arrival at full understanding awaits the passage of time until a unique, revelatory and redemptive event has taken place. Again, we may focus on one element which stands at the heart of Leroy's form, viz. the misunderstood word or expression. But this same phenomenon occurs in thirteen other places.

The chart could have been expanded to reveal even more form-critical distinctions embedded in the text. Leroy's eleven passages, for instance, are actually introduced by an array of very different forms (question, command, ambiguous greeting, demand for a sign in the wake of a symbolic act, and so forth); and some of these introductions are so intimately related to the misunderstanding which follows that a surgical separation makes nonsense of the text in which it is embedded. This means that either the entire account came down in oral tradition - in which case there are huge form-critical differences among Leroy's chosen cases - or else the evangelist has in many cases so integrated the misunderstanding itself with the entire pericope in which it lies that it is impossible to extract one from the other on formal grounds. To use Leroy's categories, if we are dealing with a riddle concealed within a dialogue, then either the form-critical status of the entire dialogue must be weighed - in which case there is too much formal diversity to allow Leroy's analysis to proceed - or he must explain more clearly on what grounds the riddle may be abstracted from the dialogue.

We must wonder, too, if it is legitimate to accept the sharp distinction between misunderstanding and not understanding adopted by several writers. Becker, as we have seen, argues that, with one exception, misunderstandings befall the Jews, and failure to understand befalls the disciples. The one apparent exception, in his view, is 4:31-34; but it is not a real exception since Jesus explains the matter to his followers, whose misunderstanding is then entirely dissolved. We reply: 
(1) In fact, the chart reveals five other instances of misunderstanding by the disciples (viz. 13:6-10; 13:27-30; $14: 4-6 ; 14: 7-10 ; 21: 20-23$ ); and all but one of them (viz. 14:4-6) also involve a verbal ambiguity. (2) Three of these do not find Jesus offering additional explanations to his disciples $(13: 6-10 ; 13: 21-30 ; 21: 20-23)$. (3) But even if 4:31-34 were the only instance of misunderstanding on the part of the disciples (as clearly it is not), it could not be legitimately dismissed on the grounds that Jesus in this instance offers an explanation following the misunderstanding, for in five cases Jesus similarly provides an explanation following misunderstandings on the part of Jews $(6: 32-35 ; 8: 31-33 ; 8: 38 \mathrm{ff}$; $8: 51-53 ; 8: 56-58)$; and in two cases of their failure to understand he does the same thing $(8: 27-28 ; 12: 27-33)$.

I am not saying there is no difference whatever between disciples and opponents; that would be absurd. It is clear, however, that there is no difference between the two groups in respect of (1) the form-critical characteristics of the pericopae describing their respective misunderstandings and failures to understand, and (2) the kinds of things the two groups misunderstand or fail to understand. Where disciples and 'Jews' differ in John's gospel, the difference turns on such things as their respective receptivity to the light, and the primacy of election. When the 'Jews' do in fact understand what Jesus is saying, they take up stones to kill him (5:18; $7: 30 ; 8: 37,58$; 10:31-33). By contrast, when the disciples understand, or think they do. (16:29), they are content with the explanation.

These are some of the factors which make the identification of a particular 'form' very difficult, and Leroy's classification, a riddle concealed in a dialogue, particularly implausible. More must be said about the nature of what is understood or misunderstood, and the inappropriateness of the 'riddle' category, but before leaving form-critical considerations we should remind ourselves of the growing reserve with which form criticism has been treated during the last few years. ${ }^{24}$

24. Cf. inter alios M. D. Hooker, 'Or. Using the Wrong Tool', Theology 75 (1972) 570-581; idem, Christology and Methodology', NTS 17 (1970/71) 480-487; G. N. Stanton, 'Form Criticism Revisited', in what about the New Testament? (Festschrift C. F. Evans; ed. 
Successive scholars have pointed out that on any possible dating of the canonical gospels, the time span for oral tradition to accomplish all that the form critics desire is painfully short; that there are good sociological and other reasons for supposing that some written records were kept even from the days of Jesus' earthly ministry, the existence of which calls into question any descent of tradition which depends solely on oral forces; that sacred oral traditions are amazingly stable over long periods of time; that even when a 'form' is legitimately identified, the identification says little about whether the community preserved it or created it; and that in either case it is at best precarious to speculate on the Sitz im Leben in which this oral shaping of the tradition occurred. I cannot repeat the arguments here; but if they are basically correct, then the foundational presuppositions of Leroy's study are vitiated. Those who depend on him must reexamine the foundations.

There can be no doubt that understanding, misunderstanding and not understanding are important themes in the fourth gospel. But form criticism is not the most helpful tool to explain them. The theme is so pervasive that distinctions between what is traditional and what is redactional do not prove helpful. Indeed, one might argue that the high degree of formal variation from case to case is evidence of how well the evangelist has

M. D. Hooker and C. Hickling; London: SCM, 1975) 1327; н. Schürmann, 'Die vorösterlichen Anfänge des Logientraditionen', Traditionsgeschichtliche Untersuchungen (Düsseldorf: Patmos, 1968) 39-65, coupled with E. E. Ellis, 'New Directions in Form Criticism', Jesus Christus in Historie und Theologie (Festschrift H. Conzelmann; ed. G. Strecker; Tibingen: Mohr, 1975) 299-315; E. Gllttgemanns, Candid Questions concerning Gospel Form Criticism (Pittsburgh: Pickwick, 1979); K. Haacker, Neutestamentliche Wissenschaft: Eine Einfuhrung in Fragestellungen und Methoden (Wuppertal: Brockhaus, 1981) 48-68; S. H. Travis, 'Form Criticism', New Testament Interpretation, ed. I. H. Marshall (Exeter: Paternoster, 1977) 153-164; D. A: Carson, 'Redaction Criticism: On the Use and Abuse of a Literary Tool', Scripture and Truth, ed. D. A. Carson and J. Woodbridge (Grand Rapids:

Zondervan, forthcoming). 
worked over the material, whatever its source, and made it his own; for it is a well known feature of this gospel that when any theme is brought up again and again, it recurs almost always with slight variations. ${ }^{25}$

2. It follows that the detailed ecclesiastical situation reconstructed by Leroy rests on no firm foundation. One may question whether his proposed gnosticizing, Jewish Christian background is very likely, ${ }^{26}$ and whether the rigid dichotomy between kerygma and catechesis can any longer be sustained; ${ }^{27}$ but as far as the focus of this paper is concerned, there are two other objections which are no less fundamental.

First, in light of the objections to the distinctive 'form' Leroy proposes, and the weaknesses of form criticism as a way of identifying a specific and well defined Sitz, Leroy's threefold division of the Johannine community (one major group in dialogue with the synagogue; and two smaller groups, one catechizing Jewish catechumens and the other more thoroughly evangelizing Samaritans who possessed some elementary knowledge of Christian truth) cannot be sustained. The view that part of the Johannine community is teaching catechumens, for instance, is ultimately based on just

25. Cf. L. Morris, 'Variations - A Feature of the Johannine Style', Studies in the Fourth Gospel (Grand Rapids: Eerdmans, 1969) 293-319.

26. Leroy's insistence that Johannine Christians grasped the fact of Jesus' ascent before they came to terms with his descent is probably right, but is not very congruent with a gnostic redeemer myth. To argue that they transformed the myth by applying Christian categories begs the question of whether the full-blown myth was so early: cf. C. Colpe, Die religionsgeschichtliche Schule: Darstellung und Kritik ihres Bildes vom gnostischen Erlösermythus (Göttingen: Vandenhoeck \& Ruprecht, 1961); E. M. Yamauchi, Pre-Christian Gnosticism (London: Tyndale, 1973). The recent publication of the Nag Hammadi texts does not overturn this fact: $c$. E. $M$. Yamauchi, 'Pre-Christian Gnosticism in the Nag Hammadi Texts?', Church History 48 (1979) 129-141.

27. Cf. esp. J. I. H. McDonald, Kerygma and Didache (Cambridge: Cambridge UP, 1980). 
one passage (4:31-34), where, says Leroy, the disciples represent ill-taught Jews, still young in the faith. On such a basis, one could argue from the one instance of misunderstanding in a Roman (18:36-37) that another part of the community is evangelizing Romans or government officials who are young in the faith. In fact, col. 11 shows the understanding of the disciples is fragile in far more places than Leroy allows; but in none of them them is there any suggestion in the text that the disciples represent Jewish catechumens. This view emerges only from a doctrinaire approach to form criticism. It is of course true that the theme of the disciples' misunderstanding in John must be explained; but as we shall see, more fruitful approaches are possible.

A second problem arises from Leroy's reconstruction of Johannine ecclesiastical history. Leroy associates the preaching of the major part of the Johannine community with the gift of the Paraclete. The 'insiders' enjoy his presence and manifest his power primarily in the preached word; the 'outsiders' do not enjoy his presence. But what is remarkable about the teaching of John regarding the Spirit/Paraclete is that there are two dualities, not one. Leroy points to those who have the spirit and those who do not, akin, for instance, to the antithesis of 14:17: the world cannot accept the Spirit of truth, but the disciples can. That is the first duality. But the second is even more pervasive. At the time Jesus is purported to speak, the Spirit has not yet been given; and his presence will be enjoyed only after Jesus returns to his Father by way of the cross and resurrection; and he bestows his spirit, or asks his Father to do so, only in the wake of that triumph $(7: 37-39$; $14: 16,23,25-26$; 15:26-27; 16:7,1215). In other words, at the time Jesus is speaking, not even the disciples possess the spirit in the fullorbed way Jesus envisages. But once this second duality, a 'now/then' duality, is seen, the parameters of a major inconsistency in Leroy's presentation stand out starkly. Leroy makes two mutually incompatible associations. (1) He associates the wilness of the largest part of the community with the presence of the Paraclete; that is, the disciples in the fourth gospel, corresponding to Christians in the Johannine church, are 'insiders'. (2) He associates Jesus, who understands everything, with the secret knowledge possessed by the Johannine community, and the 
disciples in the fourth gospel with the ill-taught Jewish catechumens: the disciples in John are 'outsiders'. The reason for this clash lies in Leroy's failure to integrate into his scheme the fourth gospel's insistence that the coming of the Spirit/Paraclete is an historical event lying beyond the period it purports to describe. ${ }^{28}$ The insider/outsider duality must be divided in two: it turns not only on the question of understanding conceived in a-temporal terms, but on a temporal axis as well. The passage of time was needed before an explanatory event of redemptive history had taken place (cf. Col. 17).

There is a growing consensus in the world of Johannine scholarship that the fourth gospel betrays a conflict between synagogue and church. The influential survey by $R$. Kysar lists Leroy in support of this consensus. 29 Whatever the merits of the general consensus, it appears rather doubtful that Leroy's conclusions are well enough grounded methodologically to be given even a supporting role.

3. Leroy's 'insider/outsider' distinctions face another hurdle. To the misunderstandings he studies he gives the designation Rätsel, 'riddle', a literary form which depends on two meanings, a general, natural one for 'outsiders', and a special, spiritual one for 'insiders'. Even if we limit ourselves to the eleven passages he studies, 'riddle' is scarcely an appropriate label for a form which, on Leroy's understanding, does not depend on a clever depth of meaning or a witty insight, but on a word-play. Jesus' audiences within the gospel itself may fail to grasp his meaning, but the readers will not, even if they do not become Christians. ${ }^{30}$ The 'special meaning' requires no profound or spiritual intuition, but lies on the surface of John's text. Any reader can see what the special meaning is, be he Jew, Muslim, atheist, Hindu, or secularist. But understanding that

28. I here assume that Jn. 20:22 cannot be reduced to a 'Johannine Pentecost' (cf. my Divine Sovereignty 141-143); but the main lines of the argument would be unaffected by another understanding of this verse.

29. The Fourth Evangelist and His Gospel (Minneapolis: Augsburg, 1975) 151.

30. I here follow R. E. Brown, Bib 51 (1970) 154. 
'special meaning' does not, in John's day or in ours, make a person a Christian. If the evangelist thinks it does - as in Leroy's construction he must - he is foolish. Leroy has grounded the entire cohesiveness of the Johannine community on a gnosticizing view of understanding (i.e. the understanding of special revelation by itself saves) without adequately weighing other Johannine themes - like the lamb of God who takes away the sin of the world, the one who dies instead of the nation, the one whose humble role not only sets an example but speaks of a 'washing' of his people which frees them from their sins $(1: 29 ; 11: 49-52$; $13: 8 ; 8: 36)$. We must ask ourselves under. what conditions the misunderstandings Leroy studies can be seen as something more than puns; for that is all they could possibly be in the Sitz im Leben of the Johannine ecclesiastical situation Leroy reconstructs.

4. Brown is certainly right in saying that Johannine misunderstandings find a synoptic analogue in the parables, where motifs of understanding and misunderstanding come into frequent play. Yet three qualifications must be registered. First, although many synoptic parables $^{31}$ are suitably analogous to Johannine misunderstandings insofar as the theme of misunderstanding itself is concerned, they are formally rather unlike most instances of misunderstandings in John (e.g. those in which a word-play is central, col. 9). On formal grounds, John 10:1-6 is somewhat closer to many synoptic parables; but this is rather exceptional. Second, there are synoptic analogues to Johannine misunderstandings beyond the parables suggested by Brown. We may remind ourselves, for instance, of ambiguous Christological titles, 32 and especially of the persistent failure of the disciples to understand that Jesus was to die and rise again, a failure akin, as far as content is concerned, to many entries in Col. 8. Or again, the kind of ambiguous answer Jesus gives in John 2:19-22, in response to a

31. See especially the discussion of R. E. Brown in his review of Leroy in Bib 51 (1970) 152-154.

32. Cf. D. A. Carson, 'Christological Ambiguities in Matthew's Gospel', in the D. Guthrie Festschrift (forthcoming). 
demand that he prove his authority, has not a few features in common with Matt. 12:38-42 and parallels. Third, we should not overlook the fact that John records so many misunderstandings, and such diverse forms of them, and should ask what this might signify.

5. None of the scholars whose work we have considered gives adequate attention to the evidence represented in Col. 17. Barrett, as we have seen, rightly points out that misunderstandings in John are not merely some literary trick by a writer given to irony, 'but represent in miniature the total reaction of Judaism to Christ'. ${ }^{33}$ But does John have the reaction of the Judaism of his own day in mind? Does he think that they continue to misunderstand the word-plays found on Jesus' lips, that all they need is to have them explained and they will become Christians? If the solution to the misunderstanding in many cases awaits the occurrence of a major redemptive event (Col. 17) - an event which is past from the perspective of his readers and therefore has already explained the relevant misunderstandings and nonunderstandings - how must we envisage the evangelist's purposes? What light is shed by these reflections on the gospel of John as a whole?

Ideally, what we now need is a detailed exegesis of each of the passages on the chart. I shall limit myself, however, to a summarizing argument in four points.

1. In most of the passages marked in Col. 17, the fourth evangelist insists that at least one of the essential ingredients necessary to an understanding of Jesus' person, teaching and purposes is the occurrence in history of certain unique redemptive events. This does not mean that the occurrence of such events guarantees a saving understanding; it does mean the nonoccurrence of such events would have precluded his audiences from any understanding in those areas.

The first $(1: 29-34)$ records the testimony of John the Baptist, to the effect that he would not have recognized Jesus as the lamb of God unless he had seen the Spirit come down from heaven as a dove and remain on him. The Baptist, in other words, was required to wait for a specific happening before his understanding on a particular point was enlightened. This instance is exceptional:

33. John 200 . 
usually the event which brings revelation is the cross/ resurrection/exaltation of Jesus. But this first passage does illustrate the kind of temporal parameter on which understanding depends.

Many details in the second passage (2:19-22) are disputed. Scholars have suggested that the original saying of Jesus concerning the destruction of the temple is irretrievably lost; or that the evangelist has misinterpreted it; or that probably Jesus was referring to his body, the church; and much more. I believe a good case can be made for an authentic saying of Jesus that was purposely ambiguous, sufficiently cryptic to be used against him at his trial (but only with disputes among the witnesses, Mark 14:59) and to be understood by his disciples, after his resurrection, as a reference to his own body and the atoning death he would suffer, fulfilling by this means the deepest purposes of the temple, and thus replacing it. ${ }^{34}$ But $I$ am not now concerned to argue the point. The important detail in the text, from the perspective of this paper, is that the evangelist insists it was only after Jesus was raised from the dead that the disciples remembered the saying and believed the Scripture ${ }^{35}$ and the words Jesus had spoken. The unavoidable conclusion is that the disciples, whatever they thought of the saying before the resurrection, did not understand it before the resurrection as they understood it after the resurrection. Before that event, they, like the Jews, may have misunderstood; or they may have left the saying out of their integrated thoughts, merely not understood. Either way, the disciples did not understand until after the resurrection. It makes no

34. Cf. inter alios F.-M. Braun, Jean le théologien, vol. 3: Sa théologie: Le mystère de Jésus-Christ (Paris: Gabalda, 1966) 81-85; L. Morris, The Gospel according to John (Grand Rapids: Eerdmans, 1971) 201-205; R. Schnackenburg, The Gospel according to John, vol. I (New York: Herder, 1968) 349-353.

35. Usually when $\gamma \rho \alpha \varphi n$ is singular in John it refers to a single text. If that is the case here, it remains difficult nonetheless to specify the particular passage in mind. It could be Ps. 16:10 (cf. Acts 2: $27 f, 31$; $13: 35)$. 
difference to the present argument if even then they were wrong in their interpretation of Jesus' saying (though I do not believe that to be the case) for the point is that the evangelist has set a framework in which the understanding of the disciples is unmistakably linked to developments in salvation history. This is a fine instance, not of vaticinium ex eventu, but of interpretatio ex eventu.

There are other passages where the evangelist achieves the same effect. He points out that the disciples fail to appreciate the scriptural significance of Jesus' triumphal entry into Jerusalem until after Jesus is glorified (12:14-16). Repeatedly in the farewell discourse, the coming of the Spirit/Paraclete is not only made future to Jesus' speaking, but the understanding by the disciples of what Jesus means is made dependent on that future coming (see esp. 14:20,26; 16:7,12-15).

This perspective varies in strength from passage to passage in the fourth gospel; but as Col. 17 indicates, explicitly or implicitly this temporal factor is very strong. The language of bread from heaven, given to be eaten by men (John 6) may have been very obscure in Jesus' day; but after the Last supper, passion and resurrection, its main lines were unmistakably clear. ${ }^{36}$ Any thoughtful reader of John's gospel can tell what Jesus' 'going away' means (e.g. 7:33-36), even if his interlocutors could not understand the clause. Jesus' insistence that by 'being lifted up' he would drive out the prince of this world and draw all men to himself is nicely explained by an aside from the evangelist (12:32f), precisely because he adopts his own post-resurrection stance to interpret the remarks he could not have expounded before Jesus' death, and which he is unwilling to treat anachronistically by putting the explanation on Jesus' lips. Many more cases could be discussed in detail but the chart is of help in pointing out where the evidence lies.

36. On this point, cf. D. A. Carson, 'Historical Tradition in the Fourth Gospel: After Dodd, What?' Gospel Perspectives II, ed. R. T. France and D. Wenham (Sheffield: JSOT, 1981) 83-145, esp. 125-126. 
2. From this it is quite clear that the fourth evangelist is able and willing to maintain a distinction between then and now, the then of the situation during Jesus' ministry, and the now of the period following Jesus' glorification and the descent of the spirit, and including the evangelist's day. This is in line with a number of recent papers, like those of D. Hill, J. D. G. Dunn and $R$. J. Bauckham, ${ }^{37}$ which, protestations notwithstanding, ${ }^{38}$ argue that the church was not given to mixing up sayings of the historical Jesus with sayings of the exalted Iord as delivered through a prophet. It is not at all clear that the evangelists feel free to read the latter back into the former, especially in passages where the disputed sayings are tied to specific historical circumstances. The counter-argument becomes doubly improbable in the gospel of John, precisely because of his persistent distinction between the two periods.

3. Many of the Johannine misunderstandings are singularly implausible, or actually incomprehensible, outside the historical framework of Jesus' life and ministry. This is recognised all too seldom. J. L. Martyn, ${ }^{39}$ for

37. D. Hill, 'On the Evidence for the creative Role of Christian Prophets', NTS 20 (1973/74) 262-274;

J. D. G. Dunn, 'Prophetic "I"-Sayings and the Jesus tradition: The importance of testing prophetic utterances within early Christianity', NTS 24 (1977/ 78) 175-198; R. J. Bauckham, 'Synoptic Parousia Parables and the Apocalypse', NTS 23 (1976/77) 162176.

38. The protestations are too complex to be treated here. They tend to divide into three groups (though these are not mutually exclusive): (1) those which hold that Christian prophecy felt free to read back sayings of the exalted Lord into the Sitz of the historical Jesus; (2) those which understand the tradition of Jesus-sayings to have been so glossed during the period of oral transmission that many anachronistic utterances were introduced; (3) those which argue the tradition grew by midrashic expansion (e.g. the work of P. Borgen, Bread from Heaven, Leiden: Brill, 1965). I hope to discuss the last category in a subsequent article.

39. Cf. note 10 above. 
instance, followed by Barrett in the second edition of his commentary, ${ }^{40}$ insists that the spirit/Paraclete, by continuing so much of the work Jesus does during the days of his flesh, actually creates the 'two-level drama' in the gospel. At the einmalig level, the gospel of John describes things that occurred once, when Jesus was discharging his ministry; and at the level of the contemporaries of the evangelist, the same events are happening again. But in the strong form of the argument advanced by Martyn (in which, for instance, John 9 can be read primarily as an account of Christian witness to Jews in the Jewish quarter of some city in the Mediterranean basin towards the end of the first century), this really will not do. Martyn's proposal recognises the continuities between Jesus and the Paraclete, but neglects the discontinuities. Jesus' death/resurrection/ exaltation, perceived as a unified event, turns a corner in salvation history and constitutes the ground on which the spirit is bequeathed. But this turning of the corner does not simply introduce more of the same, albeit on a different historical level. Far from it; for from the perspective of the disciples' understanding and faith, nothing can ever be the same again. The more we recognise that John is mightily concerned with problems of understanding, misunderstanding and not understanding, the more we are driven to ask whether the faulty understanding he treats can persist in the same way after the historical redemptive appointments needed to explain them, as they do before.

We have faced this question before in considering Leroy's book. Read by the contemporaries of the evangelist, the gospel of John will not be likely to leave Jewish readers with misunderstandings about what Jesus' terms mean, especially those that have been elucidated by the past events of the cross/resurrection/exaltation. Jewish readers may not believe this witness, or they may think it blasphemous; and they may not have the personal understanding that follows on an experience of the presence of the Father and the Son by means of the Spirit (14:23), but they cannot possibly misunderstand or fail to understand most of the cases listed in the chart. In all such cases of misunderstanding or failed understanding, only the einmalig level is coherent. Indeed, the

40. John (1978) 462 . 
more we suppose that the Johannine church is in close contact with the synagogue of its day (an almost universally adopted position today), the more we must suppose that the synagogue could not have succumbed to the same kind of misunderstandings and failed understandings that afflicted both the disciples and the Jews before the passion. Barrett sees this clearly when, in commenting on 16:25, he remarks that for the evangelist, 'the contrast is not between the multitudes on the one hand and the immediate circle of Jesus on the other, but between multitudes and disciples alike during the ministry, and the disciples after the resurrection. Cf. $2: 22$; $12: 16 ; 13: 7.14$

This does not mean that the redemptive events alone afford all understanding. There are other factors: the work of the Spirit, the place of faith, the need for elective grace or an explanatory word. But it does mean that every instance of failed understanding or misunderstanding, the overcoming of which depends primarily or exclusively on the historical actuality of the cross/ exaltation - and this includes many of Jesus' ambiguous expressions or words - could not be thought of as misunderstandings in the same sense once the cross/exaltation was history. Wherever these observations are applicable, there is a ring of historical authenticity to the misunderstandings of the gospel of John.

A rapid reading of this gospel confirms this ring of authenticity in a rather surprising way. No evangelist surpasses John in preserving the sense of confusion surrounding Jesus' identity (e.g. 6:14,26-27; 6:34,4142,$52 ; 7: 11-13,15,25-27,30-31,35,40-43$; $8: 22,25$; 9:29, $36 ; 10: 19-21 ; 12: 34)$. There are disciples who follow him, and some who strongly oppose him; but the crowds

41. Ibid. 495. Cf. Wead, Literary Devices 10; and esp. the remarks of $\mathrm{I}$. de la Potterie, 'Parole et Esprit dans S. Jean', L'Évangile de Jean: Sources, rédaction, thélogie, ed. M. de Jonge (Gembloux: Duculot, 1977) 201: 'La progression Iof the theme of word and spirit] fondamentale consiste dans le passage du temps de Jésus au temps de l'Esprit. Dès le début, certes, il s'agit de la foi. Mais celle-ci ne devient la véritable foi chrétienne qu'à partir de la Résurrection, sous l'action de l'Esprit' 
divide over him, respond with well-intentioned but illconceived acclaim when he feeds them $(6: 15)$, and debate the significance of his still ambiguous claims and demands. Historically speaking, this is realistic. What is more, the abundant confusion is a type which could not be duplicated after Jesus' crucifixion, resurrection and exaltation. There might then be confusion over the truth-claims Christianity makes, confusion over what some of its most difficult terms mean, confusion over how it proposes to relate itself to the old Testament, and confusion even over the question of whether the historical Jesus actually claimed all the things the church insists he did. But there can no longer be confusion over the meaning of the expressions or the basic nature of the truth-claims. Unbelief, yes, along with skepticism, rejection, doubt - but not this kind of confused misunderstanding. The cross and resurrection have polarized the debate.

At stake, of course, is the general historical reliability of John's witness to Jesus, and therefore also the way we envisage the descent of tradition incorporated in the fourth gospel. I have outlined elsewhere my approach to source-critical and tradition-critical problems in John, and shall not repeat myself here. 42 But B. Gerhardsson offers an apt remark: 'The evangelists tell us repeatedly that the earthly Jesus was a riddle to his people and, to a large extent, even to his disciples. Their understanding of him was, before Easter, imperfect and provisional. It was not until after Easter that the disciples thought they had achieved a clear and fully correct understanding of the mystery of Jesus. It was only then that they recognized the complete meaning of the confession "You are the Christ, the Son of the

42. Cf. D. A. Carson, 'Historical Tradition', 83-145; idem, 'Current Source Criticism of the Fourth Gospel: Some Methodological Questions', JBL 97 (1976) 411-429. Cf. L. Morris, 'The Composition of the Fourth Gospel', Scripture, Tradition and Interpretation (Festschrift E. F. Harrison; ed. W. W. Gasque and W. S. Lasor; Grand Rapids: Eerdmans, 1978) 157-175, who offers a modified version of the 'preaching notes' scheme developed by B. Lindars, The Gospel of John (London: Marshall, 1979). 
living God". It was only then that they could see with full clarity Jesus' own place in the kerygma of the reign of God. ${ }^{43}$ In W. Manson's words, 'The facts show... that the community remembered better than it understood'. ${ }^{44}$ Gerhardsson goes on to argue that this post-resurrection understanding 'influenced' the tradition, and doubtless it did. But if the gospel of John is anything to go by, the fourth evangelist, at least, knew how to preserve the distinction between what was understood in Jesus' day and what was understood only after his return to the Father.

Within this framework, the remarkable confessions of John $1: 41,45,49$, usually dismissed as of no historical value on the grounds that the synoptics do not record confessions of like clarity so early in Jesus' ministry, are perhaps not so implausible after all. If these verses are read within the context of the entire gospel of John, they sound less like the mature confessions of a late first-century church and more like the youthful exuberance of early faith. After all, something about Jesus must have prompted men to leave the Baptist and follow him. But the kind of Messiah Jesus turned out to be did not easily mesh with the mind-set of those early disciples; and so the doubts, misunderstandings, and failed comprehension began to run their sorry course.

4. Implicitly, I have been criticizing the tendency of current studies on John to read off the situation in John's church as if it lay on the surface of the text. An excellent example is a recent article by $\mathrm{J}$. $\mathrm{H}$. Neyrey, who argues that John 3 is essentially a debate between a Jewish leader and the Christian leader, just before the synagogue ban went into effect, over disputed points of epistemology and Christology. ${ }^{45}$ I believe this approach to be methodologically ill-advised; but I shall limit my counter proposals to two points. First, in its baldest form, the constant recourse to what

43. B. Gerhardsson, The Origins of the Gospel Traditions (Philadelphia: Fortress, 1979) 91.

44. W. Manson, Jesus the Messiah (London: Hodder, 1943) 14.

45. J. H. Neyrey, 'John III - A Debate over Johannine Epistemology and Christology', NovT 23 (1981) 115127. 
John's church is facing shuts out the interpreter from perceiving the real focus of many of these passages. As presented in John, the misunderstanding or failed understanding of disciple and Jew alike is in no small measure a function of their unique place in salvation history. They were unprepared to accept the notion of a humble, crucified and resurrected Messiah who would sometimes prove ambiguous in his claims - claims sufficiently in need of interpretation that their full import could be grasped by those with a traditional Jewish mind-set only after Calvary and the empty tomb. To this extent, the disciples' experience of coming to deeper understanding and faith cannot be precisely duplicated today; for it was locked into a phase of salvation history rendered forever obsolete by the triumph of Jesus' resurrection and exaltation. Doubtless there are many things to learn from their experience; but in this respect, their growth in understanding was unique. The harshest forms of modern redaction criticism fail to accommodate this fundamental point.

Second, if we then try to imagine under what circumstances this book was written, several things appear probable. The theme of misunderstanding and failed understanding is very important to John. It is not unique to him, but of the four canonical evangelists he has done the most with it. He has so written up his material, so made it his own, that the search for Jesus' ipsissima verba is largely in vain; but his constant appeal to a pre-passion setting in many of the misunderstandings he treats encourages us to think we may not be far from the ipsissima vox, however conveyed in Johannine vocabulary and style. More important, John has chosen to write a gospel, not an epistle - a gospel about a man whose ministry happened einmalig, back then; and whose death, resurrection and glorification radically altered the understanding of his followers. In what kind of setting might such things be written? Precisely because so many of the misunderstandings John treats would not be misunderstandings in his own day, it is doubtful that he includes them in order to address a church/synagogue conflict whose parameters can be read off from the surface of the text. Rather, his purpose in writing, as he has always said, was to foster belief 'that Jesus is the Christ, the Son of God' $(20: 31)$. A prolonged debate has developed over whether this verse means John is trying to deepen faith in those who have it, or engender faith in those who do not - i.e. 
whether he is trying to teach the church or evangelize the world. ${ }^{46}$ I suggest both. John takes pains to review the historical circumstances in which the first misunderstandings and incomprehension were overcome, misunderstandings and incomprehension which in large measure could not have been found in those same terms in his own circles; and in that sense he is instructing the church as to her roots, and possibly even answering the perennial Jewish question as to why Jews did not recognise Jesus when he first came. At the same time, the proclamation of these historical beginnings is climaxed by the coming to faith and understanding of Thomas, to whom the resurrected Lord says, 'Because you have seen me you have believed; blessed are those who have not seen and and yet have believed' (20:29). This verse fastens on the difference between the first historical disciples and John's readers: one group came to faith and understanding by being witnesses of the unique saving event; the others must come to the same position by believing the witnesses - including this gospel - without being present at that event. Thus there seems to be good reason for thinking that John is interested in instruction, apologetics, and evangelism. For reasons which go beyond the boundaries of this paper, I believe that his intended audience was large numbers of Hellenized Jews, along with Gentiles. I do not think that the evidence which prompts some to conclude the gospel was written about the time of the Birkat ha-Minim is very compelling; but in any case the Johannine misunderstandings, rightly considered, lend no support to that view.

46. The debate turns in part on a difficult textual variant, $\pi \iota \sigma \tau \varepsilon \cup ́ n \tau \varepsilon$ or $\pi \iota \sigma \tau \varepsilon \cup ́ \sigma n \tau \varepsilon$. But the resolution of the textual problem is not itself determinative. The present subjunctive favours the view that John is concerned to preserve the faith of believers, but it does not exclude the possibility that he wishes readers who have the kind of faith portrayed in 2:23-35 to come to real faith. Conversely, the aorist subjunctive is certainly appropriate if John is concerned primarily with evangelism; but precisely because it is an a-temporal 'tense' it cannot by itself rule out the idea of growth in faith. 
There are numerous routes from here that could be profitably explored, not least the relation between John's treatment of misunderstandings and that found in the various synoptic gospels; ${ }^{47}$ but I had better return to my roses. Doubtless misunderstandings and failed understandings in the fourth gospel are 'literary devices'; and doubtless roses have thorns and encourage aphids. Examined holistically, however, both Johannine misunderstandings and garden roses add colour, life and depth to their surroundings. Rightly interpreted,

47. The problems are especially difficult because of the continued wide acceptance of such stereotypes as Wrede's 'messianic secret' in Mark, and in Matthew the antithesis between understanding and faith postulated by $\mathrm{G}$. Barth in Tradition and Interpretation in Matthew (London: SCM, 1963) 105-111. More balanced judgments are being brought to bear on the question. On Mark, cf. C. F. D. Moule, 'On Defining the Messianic Secret in Mark', Jesus und Paulus (Festschrift W. G. Kïmmel; ed. E. E. Ellis and E. Grässer; Göttingen: Vandenhoeck \& Ruprecht, 1975) 239-252; E. Best, 'The Role of the Disciples in Mark', NTS 23 (1976/77) 377-401; and on Matthew, cf. the Cambridge dissertation to be submitted later this year by A. H. Trotter, 'Understanding and Stumbling: A Study of the Disciples' Understanding of Jesus and His Teaching in the Gospel of Matthew'. When such studies are taken into account,. I believe that even though each canonical gospel preserves distinctive emphases on the theme of misunderstanding, all of them agree on such major points as that none of the disciples really understood the passion predictions until after the events to which they pointed, that the disciples experienced a radical improvement of their understanding of a broad sweep of messianic and eschatological issues after the resurrection - and that all of the evangelists recognized this change and avoided anachronism in regard to the degree of the disciples' understanding. 
Johannine misunderstandings cannot be reduced to a literary technique which hides an undifferentiated condemnation of Judaism, still less to a cipher for some nicely defined church/synagogue conflict at the end of the first century. However worked over in Johannine idiom, they are grounded in the life-setting of the historical Jesus, whose death, resurrection and

exaltation ratified the content of the Master's teaching and personal claims while simultaneously and once for all shattering many enigmatic aspects of their form. 


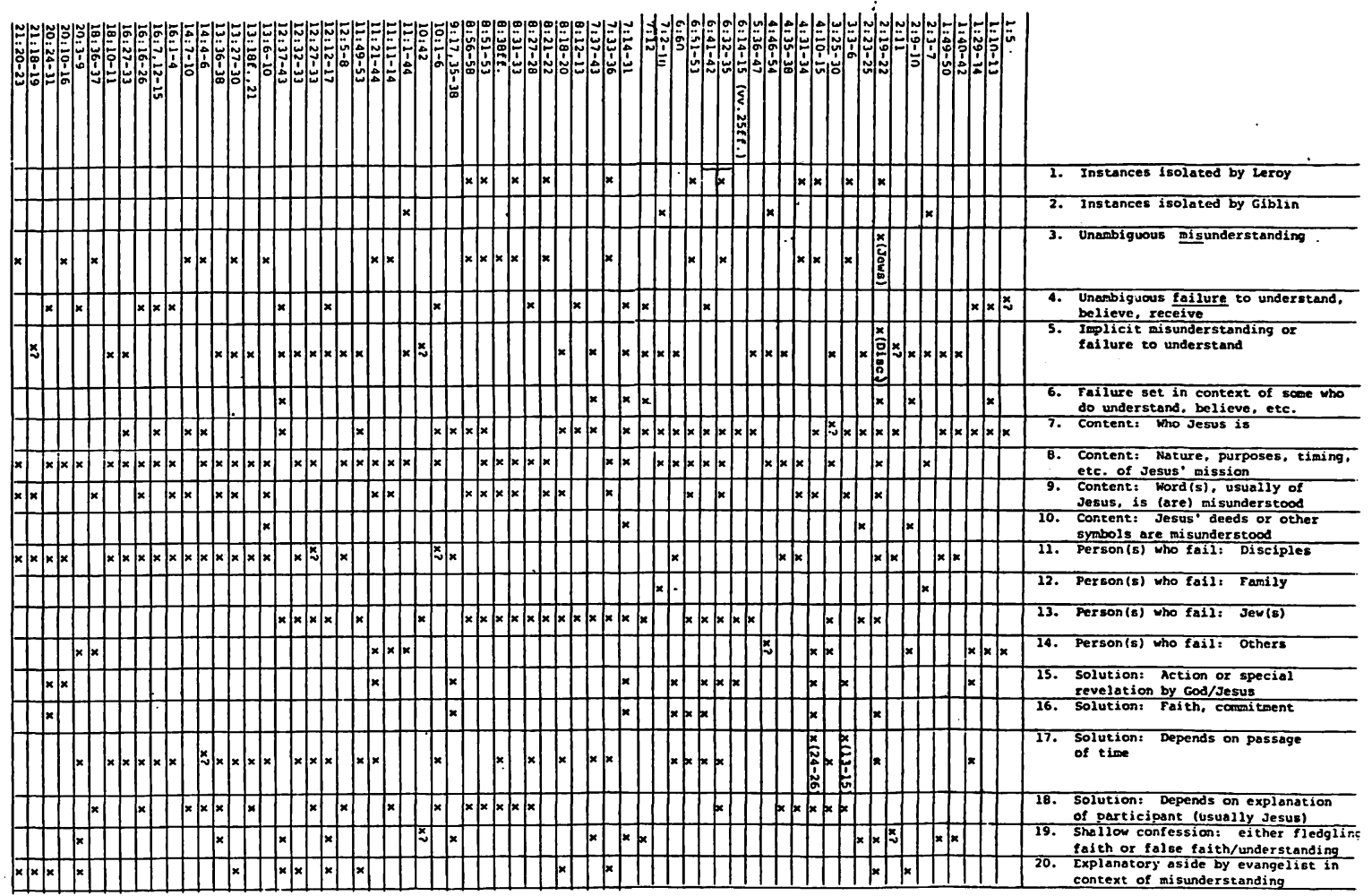

